\title{
Fortune Favors the Bold: Evidence from an Emerging Market Bank Merger
}

\author{
Dulani Jayasuriya Daluwathumullagamage \\ University of Auckland
}

This study analyses one of the largest and controversial mergers from the Philippine Banking sector and links it to M\&A theories: Firstly, this study survey prior M\&A literature to identify merger motivations, synergies and factors affecting merger outcomes. Secondly, this study conducts a case study to link prior literature to a merger in an emerging economy. This merger provides an ideal setting for a case study, subsequent links to $M \& A$ theories and generalizable lessons for future bank mergers in emerging markets. Furthermore, this study identifies key factors and steps taken by the acquiring bank management to obtain success such as doubling net income, assets and becoming the number one bank in Philippines post-merger.

Keywords: mergers, acquisitions, synergies, cultural integration, banking

\section{INTRODUCTION}

Mergers and Acquisitions (M\&A) are a key method for an organization to achieve growth, diversity, and profitability. Empirical research over the past couple of decades have revealed a great deal about M\&A motives and factors affecting their outcomes. A profusion of prior literature identifies several motives behind M\&A's and factors affecting M\&A outcomes. However, there is a gap in the literature for emerging Asian economies which this study aims to fill. In addition, majority of prior studies demonstrate that M\&A's result in value creation for the target firm shareholders. Given this setting, this paper will provide further evidence on these areas by surveying prior literature and developing a case study with a behavioral view point as well on an interesting yet controversial bank merger from Philippines. The study poses the following research questions: 1 . What are the motivations and synergies associated with this particular merger? 2. What is the pre and post-merger performance of the banks involved? 3 . What are the success factors for this particular merger? 4. What are the generalizable lessons and managerial implications from this case study? To the author's knowledge this is the first thorough case study on this particular bank merger.

This deal was selected due to its' implications on the Philippine $\left(10^{\text {th }}\right.$ fastest growing economy) banking sector and generalizable lessons to other bank mergers especially in emerging economies. Moreover, majority of M\&A deals involve the acquirer being considerably larger than the target or equal in size. However, in this particular setting, the deal was controversial since a smaller bank was attempting to acquire a considerably larger bank. The merger of the third largest bank, Equitable PCI with the fifth largest bank BDO in Philippines was initially perceived as hubris on the part of BDO management.

Several factors come into play especially with bank mergers. Firstly, the acquisition of a larger target by a smaller acquirer is rarely successful primarily due to the burden of financing. Secondly, economic 
growth also becomes a key factor enabling the merged entity to grow and increase profits. Thirdly, bank mergers are notoriously difficult and expensive due to incompatibility of systems and integration of different corporate cultures. Fourthly, regulatory approval is required for bank mergers in many countries.

Moreover, one of the key questions that arise in bank mergers involve whether branch networks are complementary or overlapping? If they are complementary, similar to the case of the Wells Fargo's takeover of Wachovia or the merger of the Nordic banks to create Nordea, then the merger is likely to be easier. If they are overlapping, there is either going to be an unpleasant loss of jobs which will lower employee morale resulting in the combined entity being inefficient. Moreover, aggressive upward acquisitions can turn sour, for example, consider the HBO or RBS case.

The traditional recipe for success is that a strong acquirer buys the weak, when the targets' price is low such as Santander with Abbey, Alliance and Leicester. Shleifer \& Vishny (2003), Rhodes-Kropf \& Viswanathan (2004) support this view stating that overvalued firm managers acquire firms undervalued in scenarios where firm value diverge from the intrinsic value. Given this setting, the BDO and Equitable PCI bank merger is an interesting case with valuable lessons that can be generalized to other bank mergers especially in emerging bank-based economies.

Researchers and practitioners generally select a case study approach for M\&A's especially when they intend to identify factors that impact an M\&A deals success or failure. Haspeslagh \& Jemison (1991), Shanley \& Correa (1992) and Marks \& Mirvis (1998) state that case studies are able to explore numerous aspects of M\&A deals occurring in different environments subject to various influences. These influences are often found too difficult to be captured by alternative analysis techniques. In addition, the case study approach enables proper value creation analysis as compared to identifying events that create value. Haleblian et al, (2009) state that case studies are a powerful method considerably underutilized in M\&A research where survey papers are more the common norm.

Moving onto the case study, at the time of BDO's initial offer to merge, Equitable PCI had capital three times as much as BDO. Analysts and regulators alike were concerned regarding the repercussions of this transaction on the Philippine banking sector and the economy. Moreover, the deal resulted in widespread negative media attention nationwide. Subsequently, the BDO merger with Equitable PCI was completed on December $27^{\text {th }}$, 2006 with the formation of BDO Uni bank.

The analysis is conducted both from a qualitative and quantitative perspective and provides evidence of value creation in M\&A's. The analysis shows that even a deal with overvaluation issues in the short run would still result in value creation in the long run (refer Shliefer and Vishny 2003). The new entity BDO Uni Bank increased their net income from 3.1 million to 6.5 million relative to BDO on average. Moreover, BDO Uni bank doubled its total assets from $300 \mathrm{Pbn}$ to $600 \mathrm{Pbn}$ and became the number one bank in Philippines. In addition, this study provides interesting policy implications to the emerging market banking sectors and the M\&A literature in general.

Section 2 conducts the literature review and deals with theories involved in M\&A outcomes. Section 3 provides a detailed qualitative and quantitative analysis. Section 4 discusses generalizable lessons and managerial implications of the study. Section 5 concludes the study.

\section{LITERATURE REVIEW}

For over three decades, academics and practitioners alike sought to identify factors behind successful mergers. Prior academic literature documents the failure of M\&A's to generate excess returns for the acquirer. Researches have also focused on understanding the main motivations for M\&A's, value creation, and determinants of M\&A returns. However, this study explores the prior literature with an aim towards differentiating between various views that affect M\&A outcomes. This literature review section is segmented into three related areas: theories on M\&A activity, motivations behind M\&A deals and factors affecting M\&A outcomes. In addition, refer to Berger, Demsetz, \& Strahan (1999) and DeYoung, Evanoff \& Molyneux (2009) for more detailed reviews of bank mergers. Table 1 summarizes the theories affecting M\&A outcomes and links them to the findings from our case study.

Journal of Applied Business and Economics Vol. 22(1) 2020 
TABLE 1

SUMMARY OF M\&A THEORIES AND CASE STUDY FINDINGS

\begin{tabular}{|c|c|c|}
\hline $\begin{array}{l}\text { M\&A Outcome } \\
\text { Theories }\end{array}$ & Prior Literature & $\begin{array}{l}\text { Our Case Study } \\
\text { Findings }\end{array}$ \\
\hline $\begin{array}{l}\text { Overvaluation: } \\
\text { M\&A's occur in highly } \\
\text { competitive markets } \\
\text { resulting in prices being } \\
\text { bid up to their intrinsic } \\
\text { value }\end{array}$ & $\begin{array}{l}\text { Sirower (1997), Haspeslagh \& Jemison (1991), Kusewitt, } \\
\text { 1985). Haspeslagh and Jemison (1991), Martin (2017) }\end{array}$ & $\begin{array}{l}\text { Contradict } \\
\text { overvaluation theory. } \\
\text { Target was } \\
\text { overvalued not the } \\
\text { Acquirer. }\end{array}$ \\
\hline $\begin{array}{l}\text { Agency Problems: } \\
\text { Agency issues in } \\
\text { M\&A's arise from } \\
\text { agents involved in } \\
\text { negotiating the } \\
\text { transaction price of the } \\
\text { deal }\end{array}$ & $\begin{array}{l}\text { Kesner et al (1994), Lubatkin (1983), Schmidt \& Fowler } \\
\text { (1990), Kroll,et al (1997), Roll, 1986), Hayward \& } \\
\text { Hambrick (1997) }\end{array}$ & $\begin{array}{l}\text { Support the Agency } \\
\text { problem. Acquirer } \\
\text { overpaid for the } \\
\text { target. }\end{array}$ \\
\hline $\begin{array}{l}\text { Management Factor: } \\
\text { The ability of the two } \\
\text { management teams to } \\
\text { work together such as } \\
\text { complimentary } \\
\text { management and prior } \\
\text { experience in M\&A's }\end{array}$ & $\begin{array}{l}\text { Shanley and Correa (1992), Datta (1991), Walsh (1988), } \\
\text { Krishnan, et al (1997), Singh and Zollo (1998), Schweiger } \\
\text { et al. (1993), Jemison \& Sitkin (1986), Larsson and } \\
\text { Finkelstein (1999) }\end{array}$ & $\begin{array}{l}\text { Support this theory } \\
\text { as complimentary } \\
\text { mangement was a } \\
\text { key factor of the } \\
\text { merger success. }\end{array}$ \\
\hline $\begin{array}{l}\text { Employee Factor: Job } \\
\text { losses post-merger } \\
\text { creating employee } \\
\text { distress is a significant } \\
\text { factor. }\end{array}$ & $\begin{array}{l}\text { Haspeslagh and Jemison (1991), Galpin and Herndon } \\
\text { (2000), Waddock \& Graves (2006) }\end{array}$ & \\
\hline & & $\begin{array}{l}\text { Support this theory } \\
\text { as the merged firm } \\
\text { was very forthright } \\
\text { with employees } \\
\text { about redundancies } \\
\text { and the status of } \\
\text { employees. }\end{array}$ \\
\hline $\begin{array}{l}\text { Distinct Cultural } \\
\text { Merger: Focus on the } \\
\text { cultural differences } \\
\text { between the acquirer } \\
\text { and target that needs to } \\
\text { be reconciled and } \\
\text { integrated post-merger. }\end{array}$ & $\begin{array}{l}\text { Buono et al. (1985), Hofstede, Neuijen, Ohayv \& Sanders } \\
\text { (1990), Ivancevich et al (1987), Schweiger \& DeNisi } \\
\text { (1988), Nahavandi \& Malekzadeh (1988), Chatterjee et al } \\
\text { (1992), Cartwright \& Cooper (1992), Forstmann (1998), } \\
\text { Schweiger \& Goulet (2005), Lodorfos \& Boateng (2006), } \\
\text { Mitleton (2006), Lin et. al. (2006), Saunders et. al. (2009), } \\
\text { Mohibullah (2009), Melkonian, Monin, \& Noorderhaven } \\
\text { (2011), Xing \& Liu (2016), Weber \& Tarba (2012), Doseck } \\
\text { (2012), Zaheer et. al. (2013), Rottig et. al. (2014), Syazliana } \\
\text { et. al. (2015), Spoor \& Mei-Tai (2017) }\end{array}$ & $\begin{array}{l}\text { Support this theory } \\
\text { in terms of the brand } \\
\text { management and } \\
\text { cultural integration } \\
\text { done by hiring out } \\
\text { side consultants by } \\
\text { the merged firm. }\end{array}$ \\
\hline
\end{tabular}




\section{Merger and Acquisition Theories}

Widespread research on M\&A activity has been conducted in the US and European markets. However, there is a dearth in research conducted on fast growing emerging markets, especially in Asia such as the Philippines. M\&A's are an important tool for businesses and this section considers the history of M\&A's. This study identifies the following benefits of M\&A's from prior literature:

Economies of scale, entry to new markets, expansion of market share, new technology acquisition and surplus fund utilization. M\&A activity generally occur in waves called merger waves and can be explained by neoclassical and market valuation theories. According to neoclassical theory, merger waves occur as a result of firms from different industries reacting to economic shocks, deregulation and new technologies. This explains the industry clustering of M\&A activities. Gort (1969), Mitchell \& Mulherin (1996) and Harford (2005) provide empirical support for this theory. Another theory suggests an association between merger waves and market valuations. According to Shleifer \& Vishny (2003)'s market valuation theory of merger waves: Deviations from fundamental values result in managers using overvalued firm stock to acquire undervalued firm assets. Rhodes-Kropf, Robinson \& Viswanathan (2005) also support the market overvaluation theory suggesting that more acquisitions occur during bubbles periods. The next section discusses motivations behind M\&A's.

\section{Merger Motivations}

Why do companies opt for M\&A's? Pfeffer (1972) states that M\&A's are caused by a need to make a firm less dependent on its environment. Haunschild (1993) explains motivations for M\&A's being associated with financial, resource dependence, managerial and agency theories. Capron \& Hulland (1999) identify market power, efficiency and effectiveness as value creating factors in M\&A's. Ahuja \& Katila (2001) identify technological and non-technological factors as M\&A motivations. They state that non-technological M\&A motivations focus on getting access to a wider range of distribution channels while technological motivations focus on entry into new markets. Chang \& Rosenzweig (2001) and Hayward (2002) associates M\&A's with market related motivations such as entering, strengthening, expanding to new markets. In addition, synergy motivations for M\&A's are identified by Golubov \& Travlos (2012), Jensen \& Ruback (1983); Bradley, Desai \& Kim (1988); Seth (1990); Doukas \& Travlos (1988); Wang \& Xie (2009); Bris \& Cabolis (2008); Scholes \& Wolfson (1990); Hayn (1989); Manzon, Sharp \& Travlos (1994); Houston, James \& Ryngaert (2001); Hoberg \& Phillips (2010).

Moreover, the following studies identify agency motivations behind M\&A's: Amihud and Lev (1981); Lewellen, Loderer \& Rosenfeld (1985); Jensen (1986); Harford (1999); Datta, Iskandar-Datta \& Raman (2001); Masulis, Wang \& Xie (2007); Lin, Officer \& Zou (2011);

Finally, the following studies identify managerial overconfidence or CEO hubris behind M\&A motivations: Roll (1986); Hayward \& Hambrick (1997); Doukas \& Petmezas (2007); Billett \& Qian (2008); Malmendier \& Tate (2008); Kolasinski \& Li (2013). In addition, prior literature conclude that M\&A's improve combined entity performance creating a competitive advantage (Lubatkin, 1983; Schweiger and Weber, 1989; Krug, Wright, and Kroll, 2013; Galpin and Herndon, 2014; Cunha, 2015; Sinclair and Keller, 2017). The next section discusses factors affecting M\&A outcomes and theories involved.

\section{Factors Influencing M\&A Outcomes \& Theories Involved}

What factors affect M\&A outcomes? Majority of prior literature show that M\&A's are value destroying leading to productivity issues and inefficiencies. This section identifies five key factors that affect M\&A outcomes: 1. Overvaluation; 2. Agency Problems; 3. Management Factor; 4. Employee Factor; 5. Cultural Merger;

1. Overvaluation: It is an implicit assumption that M\&A's occur in highly competitive markets resulting in prices being bid up to their intrinsic value. Sirower (1997) urges top management to identify synergy gain extraction methods and the relevant strategies pre-merger. Prior literature warns management not to purse overvalued M\&A deals, especially if the price exceeds their own valuations (Haspeslagh \& Jemison, 1991; Kusewitt, 1985). Haspeslagh and 
Jemison (1991) report that management view inadequate due diligence processes result in sub optimal M\&A outcomes. Martin (2017) finds that purchase prices exceeding that of market value maybe a cause for M\&A failures.

2. Agency Problems: Agency issues in M\&A's arise from agents involved in negotiating the transaction price of the deal. Kesner, et al, (1994) identify an agency problem between shareholder interests and that of the CEO during M\&A's. In addition, Lubatkin (1983), Schmidt \& Fowler (1990) state that CEO compensation increase relative to firm size. Kroll, et al (1997) find that management owned firms generate significant negative returns following a merger. Another stream of research considers CEO hubris as a key factor behind M\&A failures (Roll, 1986). Hayward \& Hambrick (1997) find that the premiums paid in M\&A's signal the amount of value to be created post-merger by the acquirer. They find a significant relationship between CEO hubris and the premium size.

3. Management Factor: The ability of the two management teams to work together such as complimentary management and prior experience in M\&A's are also important factors that may affect deal success. Shanley and Correa (1992) find that management teams of both firms agreeing on strategic objectives improve post deal performance. Datta (1991) find that managerial style differences in both firms can have a negative effect on post deal profitability. Walsh (1988) observe a significantly high turnover rate following an M\&A within a five-year time window. Krishnan, et al (1997) observe that post deal performance is positively associated with complementary management teams and negatively associated with top management turnover at the target firm. Singh and Zollo (1998) provide evidence of a negative impact on deal performance from high turnover of target firms' top management in the US banking industry. Schweiger et al. (1993) show that intra firm differences are also associated with the deal outcome.

Experience of management on M\&A's is also a key factor that affect M\&A outcomes. Integrating two different entities into one is a key challenge faced by acquiring managers in M\&A deals. Herein lies the importance of prior management experience in M\&A's. Jemison \& Sitkin (1986) state that success in M\&A's is determined by extensive planning and proper post-merger integration. Singh and Zollo (1998) find that knowledge acquired in previous M\&A deals positively impact performance in the banking industry. Larsson and Finkelstein (1999) identify a U-shape of the experience associated with M\&A's.

4. Employee Factor: Job losses post-merger creating employee distress is also considered a significant factor affecting M\&A outcomes. Subsequently, prior academics analyze the integration process post-merger and its impact on employees. Haspeslagh and Jemison (1991) find that M\&A success also depends significantly on an encouraging and co-operative environment between the two merging firms. Galpin and Herndon (2000) state the significance of effective communication during M\&A's. Waddock \& Graves (2006) state that post-merger, the acquirer often impose their policies on the combined entity jeopardizing cultural integration and employee satisfaction.

5. Distinct Cultural Merger: This particular view focus on the cultural differences between the acquirer and target that needs to be reconciled and integrated post-merger. Post-merger integration of cultures also focus on the manner in which employees are assimilated into the combined firm. Similar to Buono et al. (1985)'s firm cultural conceptualizations, Hofstede, Neuijen, Ohayv \& Sanders (1990) also find difficulties in changing firm culture. Given this setting, difficulty in cultural adaptability becomes reasonably prominent during the M\&A process. In addition, Ivancevich et al (1987) and Schweiger \& DeNisi (1988) emphasize the significance of sound communication during the M\&A process. According to them, sound communication reduces confusion and uncertainty during the M\&A process resulting in higher productivity, job satisfaction, turnover and lower absenteeism. Nahavandi \& Malekzadeh (1988) find that agreement to the M\&A deal by both acquirer and target management is a key factor of a successful merger. Chatterjee et al (1992) identify a 
significant negative correlation among cultural differences of the target and acquirer management teams and excess stock returns. However, Cartwright \& Cooper (1992) state that the key factor is the ability of the two firm employees to work together rather than the cultural differences of the two firms. Forstmann (1998) state that the post-merger integration process is a key factor in the M\&A success. Schweiger \& Goulet (2005) identify distinct cultures result in defensiveness and the maintenance of separate acquirer and target firm identities post-merger. Therefore, they state that elimination of cultural differences is key to successful integration and M\&A success. Lodorfos \& Boateng (2006), Mitleton (2006), Lin et. al. (2006) identify cultural diversity, employee treatment and communication as key factors in post-merger integration and success. Saunders et. al. (2009) state that sound communication and pre-merger audits of cultural differences are important steps to achieve proper successful cultural integration post-merger. Mohibullah (2009) state that the acquirer should implement a top down communication network among employees to decrease confusion during the M\&A integration process. Melkonian, Monin, \& Noorderhaven (2011) and Xing \& Liu (2016) find that post-merger situations and integration issues influence employee identity on both sides of the M\&A deal. Weber \& Tarba (2012) state that a lack of transparent and congruent activities during various stages of the M\&A process might lead to failures. Doseck (2012) discuss various aspects of firm culture, human resources and change management during the integration phase of M\&As. Zaheer et. al. (2013) identify that management complementarity between the acquirer and target instead of similarity would lead to successful autonomy and integration post-merger. Rottig et. al. (2014) state that poor connections among the acquirer and target limit contributions in the M\&A integration process. Syazliana et. al. (2015) identify early planning and cultural integration as being critical to M\&A success in Malaysia. Spoor \& Mei-Tai (2017) find that employee morale during an M\&A deal is largely affected by social identities and communities of both firms involved.

\section{DATA AND METHODOLOGY}

Data is collected from secondary sources for this particular study. Archival records in the form of accounting and stock market data from the firms and Bloomberg are utilized. Data is also gathered from the Philippine stock exchange and central bank. In addition, various documents from newspaper articles and consulting reports are also perused. Data triangulation is conducted to establish converging lines of evidence to make findings more robust. Explanation building technique also involves exploring rival explanations from the data. In addition, a pattern-matching logic is implemented to compare empirically based pattern. Time-series analyses of ex ante ex post merger of the two banks on accounting and stock market data is conducted.

\section{BDO Acquisition of Equitable PCI Bank (EPCIB): Case Study}

Throughout history, Philippine banks' primary method of expansion has been through investments in M\&A's and by establishing new branches. However, a key requirement for an M\&A deal is shareholder value creation. In addition, according to prior literature the cultural fit and integration post-merger is an important factor as well, even when the M\&A deal makes sense financially.

This section provides a case study analyzing one of the most important and interesting M\&A deals from the Philippine banking sector. In 2005, BDO considered expanding its market share by acquiring Equitable PCI bank with a large number of established branches. Subsequently, BDO initiated talks with Equitable PCI Bank management to discuss the possibility of a friendly takeover. Following the successful merger, newly created entity BDO Uni bank at present holds the number one position in the Philippine banking industry.

Table 2 summarizes the target, acquirer, deal characteristics and reactions to the merger announcement.' 
TABLE 2

SUMMARY OF ACQUIRER, TARGET, DEAL CHARACTERISTICS AND MERGER REACTIONS

\begin{tabular}{|c|c|c|c|}
\hline Banks Involved & Ownership & $\begin{array}{l}\text { Analyst Reaction to } \\
\text { Merger Announcement }\end{array}$ & Deal Characteristics \\
\hline $\begin{array}{l}\text { Target (Equitable } \\
\text { PCI) }\end{array}$ & $\begin{array}{l}\text { Pre-Merger Equitable PCI's key } \\
\text { shareholders }\end{array}$ & $\begin{array}{l}\text { Standard \& Poor's stated } \\
\text { that a successful merger } \\
\text { would result in an } \\
\text { improvement in } \\
\text { Equitable PCI's debt } \\
\text { rating with no change in } \\
\text { BDO's debt rating. Prior } \\
\text { to the merger, Equitable } \\
\text { PCI had a grade "B" } \\
\text { debt rating while BDO } \\
\text { had a "B+" rating. }\end{array}$ & $\begin{array}{l}\text { BDO only bid for } \\
43.50 \text { PHP per share } \\
\text { for SSS's } 26 \% \text { stake } \\
\text { in Equitable PCI. } \\
\text { Subsequently, they } \\
\text { were offering } 43.50 \\
\text { PHP per share or a } \\
10 \% \text { premium over } \\
\text { the weighted average } \\
\text { share price over a } \\
\text { mutually agreed time } \\
\text { period. }\end{array}$ \\
\hline $\begin{array}{l}\text { Equitable Banking } \\
\text { Corporation" (EBC) } \\
\text { was the former name } \\
\text { of Equitable PCI bank } \\
\text { (EPCI) when they } \\
\text { opened on September } \\
26^{\text {th }}, 1950 \text {. }\end{array}$ & $\begin{array}{l}\text { Social Security System (SSS): } \\
29 \% \text {, }\end{array}$ & $\begin{array}{l}\text { UBS claimed that } \\
\text { Equitable PCI } \\
\text { shareholders would } \\
\text { realize the BDO offer } \\
\text { attractive as it would } \\
\text { increase Equitable } \\
\text { PCI's capital adequacy } \\
\text { ratio (CAR) making it a } \\
\text { timely offer especially } \\
\text { under new International } \\
\text { Accounting Standards. }\end{array}$ & $\begin{array}{l}\text { on August } 5^{\text {th }}, 2005 \text {, } \\
\text { BDO acquired a } \\
24.76 \% \text { stake of } \\
\text { Equitable PCI. BDO } \\
\text { and Equitable PCI } \\
\text { board members } \\
\text { agreed to a modified } \\
\text { stock swap deal of } \\
1.8 \text { BDO shares } \\
\text { instead of } 1.6 \text { shares } \\
\text { for every Equitable } \\
\text { PCI share on } \\
\text { November } 6^{\text {th }} \text {. }\end{array}$ \\
\hline $\begin{array}{l}\text { In } 1999 \text {, Equitable } \\
\text { bank acquired PCI } \\
\text { bank becoming the } \\
\text { second largest bank in } \\
\text { terms of assets. }\end{array}$ & Go Family: $24.76 \%$, & $\begin{array}{l}\text { UBS forecasted an } \\
\text { increase in Equitable PCI } \\
\text { share price to } 73.60 \mathrm{PHP}, \\
\text { more than the intrinsic } \\
\text { target price of } 67 \mathrm{PHP} \\
\text { given the BDO offer. }\end{array}$ & $\begin{array}{l}\text { BDO and Equitable } \\
\text { PCI shareholders } \\
\text { approved the } \\
\text { transaction on } \\
\text { December } 27^{\text {th }} \\
2006 \text {. }\end{array}$ \\
\hline $\begin{array}{l}\text { Prior to being } \\
\text { acquired by BDO, } \\
\text { Equitable PCI was the } \\
\text { third largest domestic } \\
\text { private bank with } \\
\text { respect to loans, } \\
\text { deposits and capital. }\end{array}$ & $\begin{array}{l}\text { Government Service Insurance } \\
\text { System (GSIS): } 12.7 \% \text {, }\end{array}$ & $\begin{array}{l}\text { In } 2006, \text { many analysts } \\
\text { downgraded their rating } \\
\text { of Equitable PCI Bank to } \\
\text { a "Sell" recommendation } \\
\text { from "hold" following a } \\
21 \% \text { run-up pushed up its } \\
2006 \text { price to earnings } \\
\text { ratio to } 19.4 \text { and its price } \\
\text { to book value to } 2.4 \text {, } \\
\text { making it the most } \\
\text { expensive banking stock } \\
\text { in the Philippines. } \\
\end{array}$ & \\
\hline
\end{tabular}




\begin{tabular}{|c|c|c|c|}
\hline Banks Involved & Ownership & $\begin{array}{l}\text { Analyst Reaction to } \\
\text { Merger Announcement }\end{array}$ & Deal Characteristics \\
\hline $\begin{array}{l}\text { Offered innovative } \\
\text { and also traditional } \\
\text { deposit products, cash } \\
\text { management, } \\
\text { international, } \\
\text { commercial, } \\
\text { corporate banking, } \\
\text { money market, trust } \\
\text { and treasury services. }\end{array}$ & EBC Investments: $10.48 \%$. & Regulator Reaction & \\
\hline $\begin{array}{l}\text { Catered to a wider } \\
\text { base of retail and } \\
\text { corporate clientele } \\
\text { with an extensive } \\
\text { distribution network. }\end{array}$ & Post Merger key shareholders & $\begin{array}{l}\text { Equitable PCI was given } \\
\text { till January } 31^{\text {st }} \text { to } \\
\text { consider the deal. }\end{array}$ & \\
\hline Acquirer (BDO) & $\begin{array}{l}\text { SM Investments Corporation: } \\
85.6 \%\end{array}$ & $\begin{array}{l}\text { GSIS initially opposed } \\
\text { the deal and considered a } \\
\text { counter proposal of a } \\
\text { merger with BDO where } \\
\text { Equitable PCI would be } \\
\text { the surviving firm. }\end{array}$ & \\
\hline $\begin{array}{l}\text { BDO or commonly } \\
\text { known as Banco De } \\
\text { Oro was publicly } \\
\text { listed on the } \\
\text { Philippine Stock } \\
\text { Exchange in } 2002 \text {. }\end{array}$ & $\begin{array}{l}\text { Trans Middle East Philippines } \\
\text { Equities: } 7.13 \%\end{array}$ & $\begin{array}{l}\text { Philippine central bank } \\
\text { and the Securities } \\
\text { Exchange Commissions' } \\
\text { approval for the deal was } \\
\text { obtained in early } 2007 .\end{array}$ & \\
\hline $\begin{array}{l}\text { In 2001, BDO } \\
\text { acquired } 57 \text { branches } \\
\text { nationwide by } \\
\text { merging with Dao } \\
\text { Heng Philippines. }\end{array}$ & $\begin{array}{l}\text { SM Investments Corporation: } \\
40.87 \% \text {. }\end{array}$ & Competition & \\
\hline $\begin{array}{l}\text { The following year } \\
\text { BDO acquired } 66 \\
\text { branches with } 11 \mathrm{Pbn} \\
\text { portfolio of deposits } \\
\text { by merging with } \\
\text { Banco Santader and } \\
\text { Santader Investment } \\
\text { Securities Philippines. }\end{array}$ & & $\begin{array}{l}\text { Foreign investors were } \\
\text { also interested in } \\
\text { Equitable PCI and } \\
\text { submitted a bid of } 90 \\
\text { PHP each for SSS shares; } \\
\text { These Investor's identity } \\
\text { was not made public. }\end{array}$ & \\
\hline
\end{tabular}




\begin{tabular}{|c|c|c|c|}
\hline Banks Involved & Ownership & $\begin{array}{l}\text { Analyst Reaction to } \\
\text { Merger Announcement }\end{array}$ & Deal Characteristics \\
\hline $\begin{array}{l}\text { In 2004, BDO } \\
\text { initiated proceedings } \\
\text { to acquire the } 26 \% \\
\text { stake of Equitable } \\
\text { PCI bank from Social } \\
\text { Security Systems } \\
\text { (SSS). The Philippine } \\
\text { government was in } \\
\text { possession of the } \\
\text { remaining } 12 \% \text { stake } \\
\text { via Government } \\
\text { Service Insurance } \\
\text { System (GSIS). }\end{array}$ & $\begin{array}{l}\text { In addition, BDO further } \\
\text { increased their capital adequacy } \\
\text { ratio from } 2 \% \text { to } 3 \% \text { by raising } \\
10 \text { Pbn of tier } 2 \text { capital; } \\
\text { Following the merger, BDO } \\
\text { Unibank[1] emerged as the top } \\
\text { most bank with regard to assets, } \\
\text { toppling Metropolitan Bank as of } \\
\text { the end of } 2008 \text {. Subsequently, } \\
\text { the assets of BDO Unibank } \\
\text { amounted to } 808.04 \mathrm{Pbn} \text {, edging } \\
\text { out Metrobank, with } 758.48 \mathrm{Pbn} \\
\text { of total assets. }\end{array}$ & $\begin{array}{l}\text { GSIS stated that offers } \\
\text { must be submitted by } \\
\text { March } 6^{\text {th }} \text { to the bidding } \\
\text { process for their shares at } \\
\text { a minimum value of } 92 \\
\text { PHP per share or higher. }\end{array}$ & \\
\hline $\begin{array}{l}\text { BDO ranked 5th, 6th } \\
\text { and } 8 \text { th with respect } \\
\text { to resources and } \\
\text { loans, deposits and } \\
\text { capital respectively } \\
\text { among the } 41 \\
\text { commercial banks in } \\
\text { Philippines as of } \\
\text { December } 2005 \text {. }\end{array}$ & & & \\
\hline
\end{tabular}

SM Investment Corporation: Henry Sys' Groups' premier bank, Banco de Oro or commonly known as BDO was interested in acquiring Equitable PCI (EPCI) since 2003. BDO subsequently announced intentions of acquiring 10\% of EPCI's treasury stock. Equitable Card Network dominated the credit card industry in Philippines as a merchant acquirer and a third-party processor providing them ample motivation to increase their retail lending. PCI Capital Corporation was a popular name in investment banking and PCI leasing and Finance possessed a high capital base and a large clientele network. This acquisition of PCI bank by Equitable bank resulted in a merger wave in the Philippine banking sector. Not one to be left behind, BPI acquired Far East Bank targeting the number one position in banking and claiming it for a short time. Then, continued on a merging spree with Asian Bank, Solid Bank, Philippine Banking Corp and Global Bank to finally become the largest bank in Philippines. Hence, Equitable bank merging with PCI in 1999 resulted in a consolidation of the largely fragmented Philippine Banking Sector to some extent. Figure 1 shows the ownership structure of Equitable PCI bank pre-merger. 
FIGURE 1

SHAREHOLDERS OF EQUITABLE PCI BANK (IN 2003)

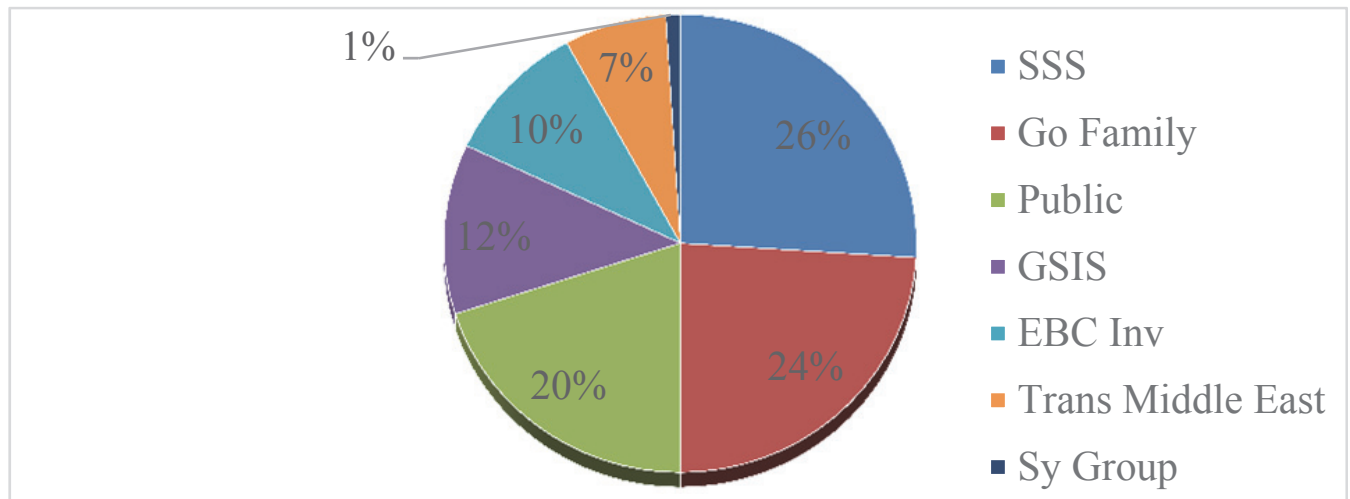

Table 4 summarizes the motivations of $\mathrm{BDO}$, benefits to all stakeholders involved, merger synergies and success factors.

TABLE 3

SUMMARY OF MERGER MOTIVATIONS, SYNERGIES, BENEFITS AND SUCCESS FACTORS

\begin{tabular}{|c|c|c|c|}
\hline BDO Motivation & Benefits & Merger Synergies & Success Factors \\
\hline $\begin{array}{l}\text { Belief of success } \\
\text { by BDO top } \\
\text { management } \\
\text { (reassurance the } \\
\text { merged entity can } \\
\text { lead the banking } \\
\text { sector; be bolder). }\end{array}$ & BDO Stakeholders & $\begin{array}{l}\text { Complementary markets } \\
\text { and clientele }\end{array}$ & $\begin{array}{l}\text { Successfully integrated two } \\
\text { distinct banking cultures. }\end{array}$ \\
\hline $\begin{array}{l}\text { Competitors } \\
\text { (Defeat of a key } \\
\text { competitor), } \\
\text { vulnerability of } \\
\text { other competitors } \\
\text { such as Metro } \\
\text { bank, future } \\
\text { obstacles from } \\
\text { other competitors). }\end{array}$ & $\begin{array}{l}\text { Substantial revenue and cost } \\
\text { synergies }\end{array}$ & $\begin{array}{l}\text { Diverse products and } \\
\text { services }\end{array}$ & $\begin{array}{l}\text { Both management teams } \\
\text { agreed upon the merger. }\end{array}$ \\
\hline $\begin{array}{l}\text { Expansion } \\
\text { (increasing BDO } \\
\text { franchise value). } 4 . \\
\text { Overvalued stock } \\
\text { (Excess cash for } \\
\text { acquisitions). }\end{array}$ & $\begin{array}{l}\text { Dominant pro-forma market } \\
\text { position }\end{array}$ & $\begin{array}{l}\text { Complementary } \\
\text { technologies \& assets }\end{array}$ & $\begin{array}{l}\text { Both management teams } \\
\text { had prior experience in } \\
\text { mergers. }\end{array}$ \\
\hline Future vision & $\begin{array}{l}\text { Enhanced distribution } \\
\text { network }\end{array}$ & $\begin{array}{l}\text { Diverse employee skill } \\
\text { sets }\end{array}$ & $\begin{array}{l}\text { Revenue synergies were } \\
\text { readily identified and } \\
\text { utilized. }\end{array}$ \\
\hline
\end{tabular}




\begin{tabular}{|c|c|c|c|}
\hline BDO Motivation & Benefits & Merger Synergies & Success Factors \\
\hline $\begin{array}{l}\text { Wealth creation } \\
\text { (Financial). }\end{array}$ & $\begin{array}{l}\text { Improved balance sheet } \\
\text { management }\end{array}$ & $\begin{array}{l}\text { BDO gained a soundly } \\
\text { established operation in } \\
\text { prime fee generating } \\
\text { departments such as trust } \\
\text { banking, credit cards and } \\
\text { remittances }\end{array}$ & $\begin{array}{l}\text { Cost efficiencies were } \\
\text { identified and efficiently } \\
\text { utilized. }\end{array}$ \\
\hline \multirow[t]{6}{*}{$\begin{array}{l}\text { Legislative support } \\
\text { (Deal was } \\
\text { eventually } \\
\text { supported by the } \\
\text { Philippine central } \\
\text { bank and the } \\
\text { Securities and } \\
\text { Exchange } \\
\text { Commission). }\end{array}$} & $\begin{array}{l}\text { Broader customer base and } \\
\text { relationships (establishes } \\
\text { scale, exposure to regional } \\
\text { economic diversity and } \\
\text { additional platform for } \\
\text { growth). }\end{array}$ & $\begin{array}{l}\text { Substantial profit } \\
\text { enhancement was } \\
\text { achieved through } \\
\text { improved product and } \\
\text { enhanced distribution } \\
\text { network, greater } \\
\text { investment in new } \\
\text { products. }\end{array}$ & $\begin{array}{l}\text { Improved balance sheet } \\
\text { management. }\end{array}$ \\
\hline & $\begin{array}{l}\text { Market leading position in } \\
\text { core business lines. }\end{array}$ & $\begin{array}{l}\text { The combined entity } \\
\text { took opportunities to } \\
\text { increase revenues by } \\
\text { cross selling the } \\
\text { expanded product } \\
\text { offerings and customer } \\
\text { base as well as its } \\
\text { affiliation with the SM } \\
\text { Group network. }\end{array}$ & $\begin{array}{l}\text { Affiliation of a large block- } \\
\text { holder (SM group) } \\
\text { provided better monitoring } \\
\text { and a positive signal to the } \\
\text { markets. }\end{array}$ \\
\hline & $\begin{array}{l}\text { Accretive to EPS (Accretive } \\
\text { merger for BDO with } \\
\text { Equitable PCI's strong } \\
\text { predicted cash flows). }\end{array}$ & & Employee Engagement \\
\hline & $\begin{array}{l}\text { Increased product } \\
\text { diversification }\end{array}$ & & $\begin{array}{l}\text { BDO's President and } \\
\text { senior leadership endorsed } \\
\text { and led the employee } \\
\text { engagement initiative }\end{array}$ \\
\hline & $\begin{array}{l}\text { Long term growth projects } \\
\text { (Equitable PCI's profitable } \\
\text { credit card business). }\end{array}$ & & $\begin{array}{l}\text { Human resources was } \\
\text { segmented similar to } \\
\text { customer segmentation by } \\
\text { collaborating with key } \\
\text { business and department } \\
\text { heads to understand } \\
\text { various needs and concerns } \\
\text { of a diverse employee } \\
\text { group }\end{array}$ \\
\hline & $\begin{array}{l}\text { Proven management teams } \\
\text { (both management teams } \\
\text { possessed valuable experience } \\
\text { from past successful mergers, } \\
\text { solid shareholder returns and } \\
\text { cash flow generation). }\end{array}$ & & $\begin{array}{l}\text { Emphasizing on brand } \\
\text { implementation through } \\
\text { actionable behavior and } \\
\text { linking the same actions to } \\
\text { desired customer } \\
\text { experiences }\end{array}$ \\
\hline
\end{tabular}




\begin{tabular}{|c|c|c|c|}
\hline \multirow[t]{2}{*}{ BDO Motivation } & Benefits & Merger Synergies & Success Factors \\
\hline & Equitable PCI Stakeholders & & $\begin{array}{l}\text { Piloting and promoting } \\
\text { programs that } \\
\text { demonstrated positive } \\
\text { business impact of } \\
\text { engagement }\end{array}$ \\
\hline & $\begin{array}{l}\text { Initially there was resistance } \\
\text { from the Equitable PCI main } \\
\text { shareholder GSIS, the rest of } \\
\text { the Equitable PCI } \\
\text { shareholders were swayed by } \\
\text { the attractive acquisition price } \\
\text { and future benefits from } \\
\text { BDOs' dividend policy. }\end{array}$ & & $\begin{array}{l}\text { Creating and quickly } \\
\text { implementing scalable } \\
\text { solutions readily delivered } \\
\text { through digital channels. }\end{array}$ \\
\hline & $\begin{array}{l}\text { Merger would provide a } \\
\text { stronger platform to execute } \\
\text { Equitable PCI's growth plans. }\end{array}$ & & \\
\hline & $\begin{array}{l}\text { From Equitable PCI } \\
\text { customers' point of view, the } \\
\text { merger provided better access } \\
\text { to a wider range of products } \\
\text { and a better customer } \\
\text { experience. }\end{array}$ & & \\
\hline & $\begin{array}{l}\text { From Equitable PCI } \\
\text { employees' point of view, the } \\
\text { strong re-branding of the } \\
\text { merged entity provided a } \\
\text { strong cultural fit. }\end{array}$ & & \\
\hline & $\begin{array}{l}\text { BDO completed the merger } \\
\text { with Equitable PCI in } 2007 \\
\text { and renamed itself as BDO } \\
\text { Uni bank. }\end{array}$ & & \\
\hline
\end{tabular}

Hence, given the above rationale, BDO justified this deal as a key strategic merger. Cost savings from the merger would arrive from overlaps and duplications from 120 branches. Revenue benefits would arise with size and scale, as the combined entity would rank No. 1 in all major sectors. The BDO offer implied a 2.3 times swap ratio. At the time of the initial offer from BDO, Equitable PCI management viewed the deal would be dilutive in the first two years and finally breaking even in the third year. In addition, the financing strategy for the deal was structured to maintain BDO's solid investment-grade credit rating. Moreover, market analysts reiterated that BDO is a top performer with a target price of 47 PHP. Hence, while the deal would be initially dilutive to BDO, this would outweigh the strategic transformation the deal would bring to the bank.

\section{Empirical Analysis of the Merger}

The merger between Equitable PCI bank (ranked $3^{\text {rd }}$ ) and BDO (ranked 5th) resulted in BDO Unibank (largest bank in Philippines). The tables and graphs provide empirical evidence pre and postmerger for both banks from financial statements, share prices, public and private information gathered from various parties involved in the merger. Figures 2 and 3 shows the stock price reaction to the merger announcement and merger completion for both banks. 
FIGURE 2

HISTORICAL BDO AND PCI STOCK PRICE

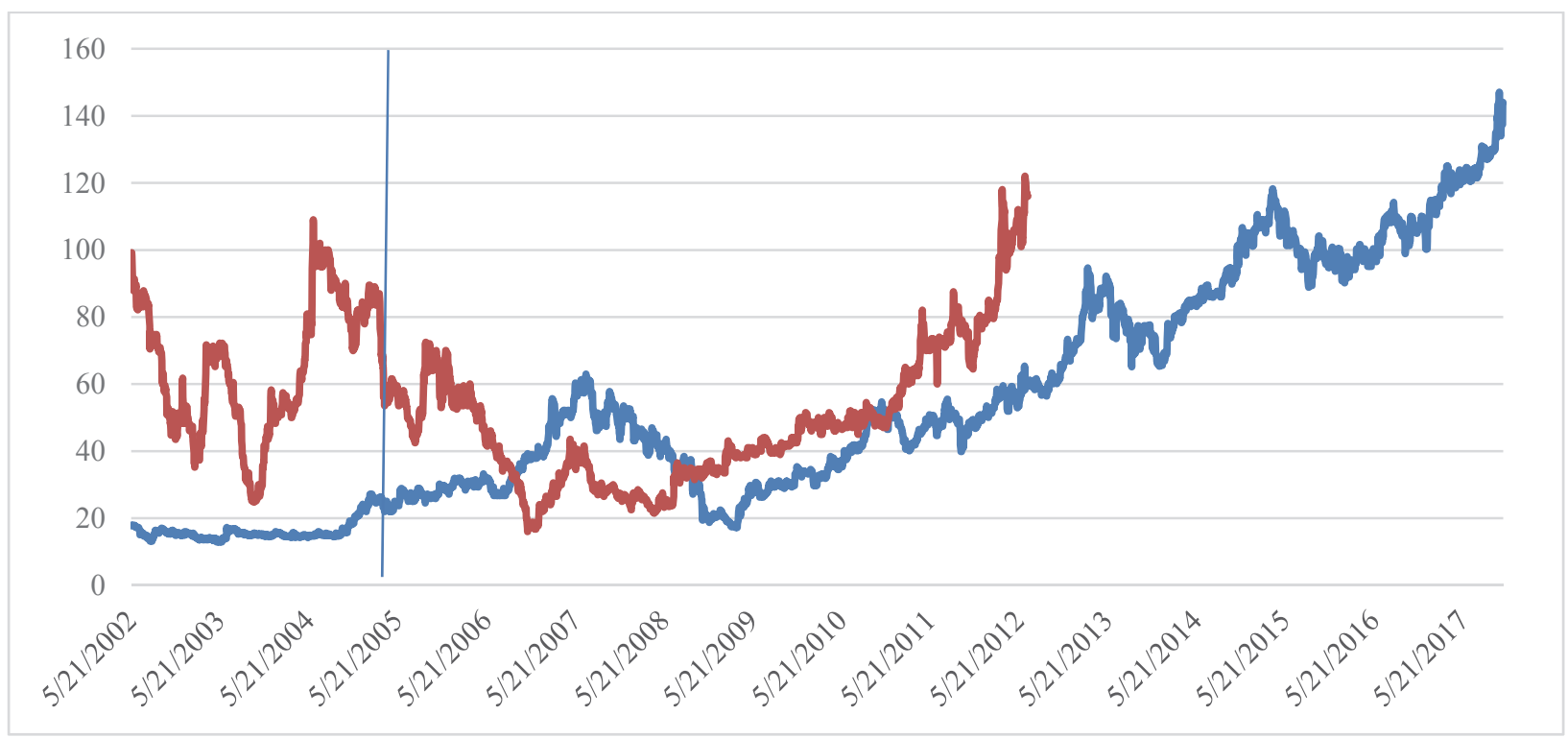

Note: The blue line depicts BDO close price and the red line depicts Equitable PCI stock price.

FIGURE 3

PRE AND POST MERGER ANNOUNCEMENT EFFECT ON BDO AND EQUITABLE PCI STOCK PRICE

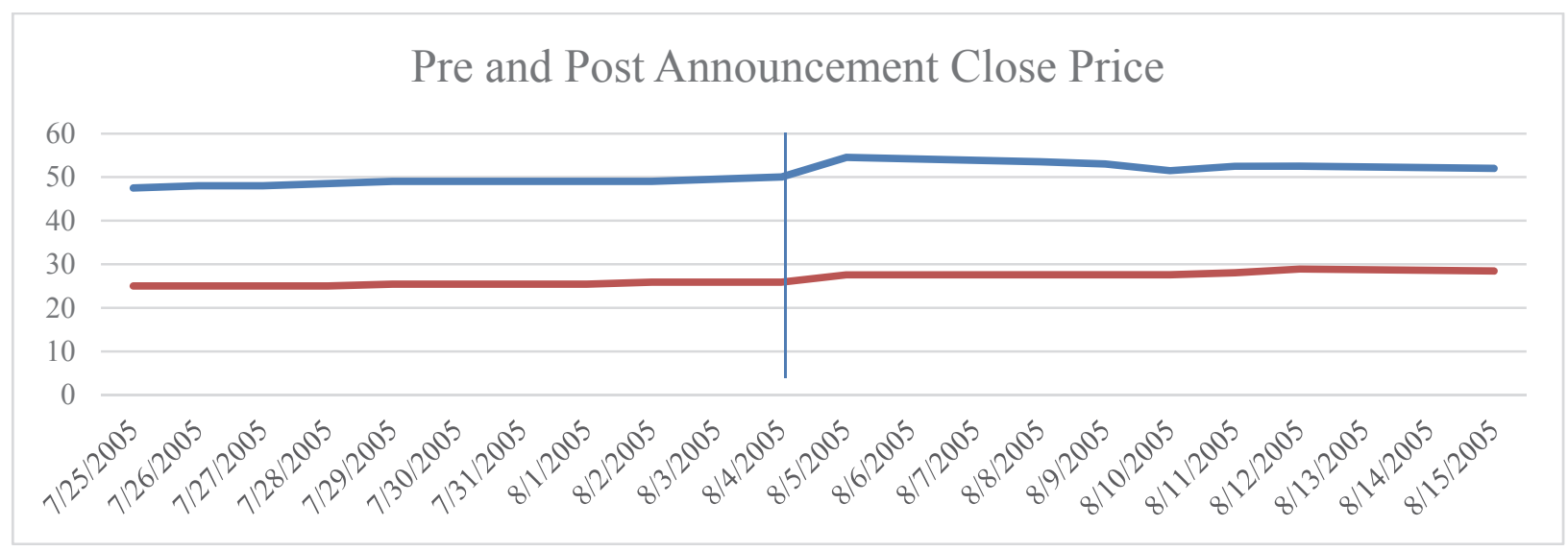

Note: The blue line depicts BDO close price and the red line depicts Equitable PCI stock price.

A correlation analysis was conducted on the total liabilities, total assets, and the revenue of BDO and Equitable PCI from 2003 to 2006. Total assets and liabilities have a significant positive correlation of 0.76 and 0.8 respectively. This result can be explained as both banks mirroring each other's behavior by expanding their assets and liabilities to obtain more market share as competitors. In addition, there is a negative significant correlation between revenues of the two banks identifying them as competitors. Moreover, this gives further support to BDO's motives of taking out a strong competitor and at the same time obtaining more market share by acquiring Equitable PCI. 
TABLE 4

PHILIPPINE BANK RANKINGS WITH REGARD TO ASSET SIZE GIVEN IN PESO BILLION EXCLUDING FOREIGN AND DEVELOPMENT BANKS, PRE MERGER IN 2004

\begin{tabular}{lcccccccc}
\hline & & & & & & & \\
& Rank & Assets & Rank & Loans & Rank & Deposits & Rank & Capital \\
\hline Metro bank & 1 & 470.6 & 1 & 243.7 & 1 & 345.7 & 2 & 53.4 \\
BPI & 2 & 394.8 & 2 & 162.2 & 2 & 314.7 & 1 & 55.0 \\
Equitable PCI & 3 & 293.5 & 3 & 134.2 & 3 & 189.6 & 3 & 44.4 \\
PNB & 4 & 220.2 & 5 & 78.4 & 4 & 163.5 & 4 & 24.0 \\
BDO & 5 & 169.8 & 6 & 69.9 & 5 & 121.4 & 6 & 19.6 \\
RCBC & 6 & 152.2 & 4 & 83.2 & 6 & 108.2 & 8 & 16.2 \\
Allied Bank & 7 & 118.5 & 8 & 47.2 & 7 & 92.7 & 9 & 15.4 \\
China Bank & 8 & 116.4 & 7 & 50.8 & 8 & 85.5 & 5 & 20.2 \\
UCPB & 9 & 104.9 & 9 & 46.5 & 9 & 79.4 & 17 & 4.1 \\
Union Bank & 10 & 100.3 & 10 & 39.1 & 10 & 56.6 & 7 & 16.6 \\
Security & 11 & 82.7 & 11 & 38.2 & 11 & 51.7 & 10 & 10.8 \\
\hline
\end{tabular}

Source: Philippine Central Bank as of December 2004.

Table 4, shows that BDO had 304Pbn while Equitable PCI had $345 \mathrm{Pbn}$ of total assets on December 2006. Post-merger total assets of BDO Unibank increased to $617 \mathrm{Pbn}$. Prior to the merger, Equitable PCI and BDOs' net loans were close to approx. $100 \mathrm{Pbn}$ and expanded to $315 \mathrm{Pbn}$ post-merger. Moreover, total liabilities and total deposits of Equitable PCI and BDOs' increased from $297 \mathrm{Pbn}$ and $280 \mathrm{Pbn}$ in 2006 to $556 \mathrm{Pbn}$ in 2007 and from $229 \mathrm{Pbn}$ and $241 \mathrm{Pbn}$ to $445 \mathrm{Pbn}$ in 2007 respectively.

TABLE 5

YEAR ON YEAR GROWTH OF THE TARGET (EQUITABLE PCI), ACQUIRER (BDO) AND NEW ENTITY (BDO UNI BANK) BALANCE SHEET ANALYSIS, PRE AND POST-MERGER IN PESO BILLION END OF THE YEAR

\begin{tabular}{lccc}
\hline & 2007 & 2006 & 2006 \\
\hline Balance Sheet & BDO Uni bank & BDO & Equitable PCI \\
Assets & & & \\
Net Loans & 315.1 & 127.93 & 111.83 \\
Total Assets & 617.42 & 304.47 & 345.14 \\
Liabilities \& Shareholder's Equity & & \\
Total Deposits & 445.4 & 229.37 & 241.8 \\
Total Liabilities & 556.88 & 280.04 & 297.66 \\
\hline
\end{tabular}

Source: BDO, Equitable PCI and BDO Uni bank financial statements.

Table 5, shows that Equitable PCI bank and BDO had net interest incomes of $13 \mathrm{Pbn}$ and $8 \mathrm{Pbn}$, in 2006 which increased to $21 \mathrm{Pbn}$ in 2007 post-merger. Moreover, Equitable PCI and BDO had a net income of 3.27 $\mathrm{Pbn}$ and 3.13 $\mathrm{Pbn}$ in 2006 December which post-merger increased to 6.52 $\mathrm{Pbn}$. Therefore, Both Tables 4 and 5 show evidence of significant expansions in the income and balance sheet of BDO Unibank, resulting in value creation post-merger. 
TABLE 6

YEAR ON YEAR GROWTH OF THE TARGET (EQUITABLE PCI), ACQUIRER (BDO) AND NEW ENTITY (BDO UNI BANK) INCOME STATEMENT ANALYSIS, PRE AND POSTMERGER IN PESO BILLION END OF THE YEAR

\begin{tabular}{lccc}
\hline & 2007 & 2006 & 2006 \\
\hline Income Statement & BDO Uni bank & BDO & Equitable PCI \\
Net Interest Income & 21.49 & 8.33 & 13.12 \\
Net Income & 6.52 & 3.13 & 3.27 \\
\hline
\end{tabular}

Source: BDO, Equitable PCI and BDO Uni bank financial statements.

TABLE 7

KEY RATIOS OF THE TARGET (EQUITABLE PCI), ACQUIRER (BDO) AND NEW ENTITY (BDO UNI BANK) PRE AND POST-MERGER END OF THE YEAR

\begin{tabular}{lccc}
\hline & 2007 & 2006 & 2006 \\
\hline Profitability \% & BDO Uni bank & BDO & Equitable PCI \\
NIM & 4.0 & 3.3 & 4.3 \\
ROA & 1.41 & 1.16 & 0.17 \\
Diluted EPS & 2.56 & 2.89 & 4.88 \\
BV per share & 23.45 & 22.91 & 63.7 \\
\hline
\end{tabular}

Source: BDO, Equitable PCI and BDO Uni bank financial statements.

Table 6 show several key ratios of BDO, Equitable PCI and BDO Uni bank post-merger. In December 2006, Equitable PCI had a net interest margin of 4.3\%, while BDO's was 3.3\% which settled at $4 \%$ post-merger. Implied interest payments are a key component in the Net Interest Margin (NIM) calculation. In the case of BDO and Equitable PCI bank, implicit interest payment effects on NIM showed signs of concentration following the consolidation period due to changes in combined entity operations and revenue structure. Equitable PCI bank and BDOs' return on assets of $0.18 \%$ and $1.16 \%$ in 2006 increased to $1.41 \%$ in 2007 for the combined entity BDO Uni bank. Return on assets (ROA) measure effectiveness of the firm's assets utilization in generating profits net of expenses. Hence, these results show improved ROA numbers possibly due to new combined entity better managing its assets to generate profits.

Moreover, BDO Uni bank enjoyed a larger client base and an increase in number of offices and branches widely dispersed across the Philippines post-merger. Interestingly, Equitable PCI and BDO had earnings per share (EPS) of 4.89 and 2.89 respectively in 2006 which decreased to a 2.57 post-merger. This can be due to an acquisition being an immediate cost to shareholders bringing in value creation and revenues only in subsequent years resulting in a lower EPS for the combined entity immediately. As of 2015, BDO Uni banks EPS remain at a healthy 6.84. Following the merger in August 2007 BDO Uni bank was given an improved debt rating especially with better conditions in the Philippine banking sector. At the time of the re-rating BDO Uni bank shares traded with a 2.8 price to book ratio and a prospective $\mathrm{P} / \mathrm{E}$ ratio of 18 .

In addition, Equitable PCI and BDO had a book value per share of 63.7 and 22.91 in 2006 which settled at 23.45 post-merger. Eight years post-merger, book value per share settled at 53.17 in 2015 due to increases in growth, productivity and financial stability. Figure 4 shows Equitable PCI banks' revenue figures from 2003 to 2006. A small decline in revenue is observed in 2005 due to some depositors and borrowers fleeing the bank due to uncertainties arising from a possible merger with BDO. 
TABLE 8

\begin{tabular}{|c|c|c|c|c|c|c|}
\hline Bank Name & Year & $\begin{array}{c}\text { Net } \\
\text { Goodwill }\end{array}$ & $\begin{array}{c}\text { Total Interest } \\
\text { income }\end{array}$ & $\begin{array}{c}\text { Provisions Credit } \\
\text { Losses } \\
\end{array}$ & $\begin{array}{c}\text { Total } \\
\text { Revenue }\end{array}$ & $\begin{array}{c}\text { Total } \\
\text { Share } \\
\text { Capital } \\
\end{array}$ \\
\hline $\mathrm{BDO}$ & 2004 & 0 & 6767 & 187 & 3420 & 9145 \\
\hline $\mathrm{BDO}$ & 2005 & 600 & 8901 & 292 & 4583 & 9481 \\
\hline $\mathrm{BDO}$ & 2006 & 662 & 11502 & 245 & 6086 & 9620 \\
\hline BDO Uni bank & 2007 & . & 12826 & 1429 & 9696 & 16163 \\
\hline BDO Uni bank & 2008 & . & 14256 & 774 & 9506 & 23020 \\
\hline BDO Uni bank & 2009 & . & 18344 & 1288 & 12373 & 28020 \\
\hline BDO Uni bank & 2010 & . & 18495 & 1629 & 12994 & 29736 \\
\hline BDO Uni bank & 2011 & . & 24849 & 1642 & 13755 & 31074 \\
\hline BDO Uni bank & 2012 & . & 30020 & 1475 & 16956 & 34679 \\
\hline BDO Uni bank & 2013 & 1482 & 34569 & 1600 & 18228 & 40958 \\
\hline BDO Uni bank & 2014 & . & 30773 & 1293 & 17008 & 40958 \\
\hline Equitable PCI & 2004 & 15240 & 9781 & 1035 & 5954 & 7270 \\
\hline Equitable PCI & 2005 & 15680 & 11891 & 715 & 6985 & 7270 \\
\hline Equitable PCI & 2006 & . & 9742 & 407 & 7285 & 7270 \\
\hline
\end{tabular}

TABLE 9

\begin{tabular}{lccccc}
\hline Bank Name & Year & $\begin{array}{c}\text { Customer } \\
\text { Acceptance }\end{array}$ & Long Term Debt & $\begin{array}{c}\text { Total Deposits } \\
\text { By Banks }\end{array}$ & $\begin{array}{c}\text { Total Deposits } \\
\text { by Customers }\end{array}$ \\
\hline BDO & 2004 & 0 & 27334 & 0 & 112445 \\
BDO & 2005 & 10047 & 19939 & 5412 & 147146 \\
BDO Uni bank & 2006 & 0 & 45291 & 0 & 199858 \\
BDO Uni bank & 2007 &. & 44325 &. & 339769 \\
BDO Uni bank & 2008 &. & 74656 &. & 481318 \\
BDO Uni bank & 2009 &. & 67366 &. & 631749 \\
BDO Uni bank & 2010 &. & 60062 &. & 686561 \\
BDO Uni bank & 2011 &. & 88745 &. & 774384 \\
BDO Uni bank & 2012 &. & 105849 &. & 858556 \\
BDO Uni bank & 2013 & 37259 & 73926 & 8067 & 1118930 \\
BDO Uni bank & 2014 &. & 84167 &. & 1375057 \\
Equitable PCI & 2004 & 25849 & 17224 & 108 & 187259 \\
Equitable PCI & 2005 & 18521 & 32448 & 76 & 206130 \\
Equitable PCI & 2006 &. & 31543 & 122 & 223119 \\
\hline
\end{tabular}


FIGURE 4

REVENUES OF EQUITABLE PCI BANK FROM 2003 TO 2006

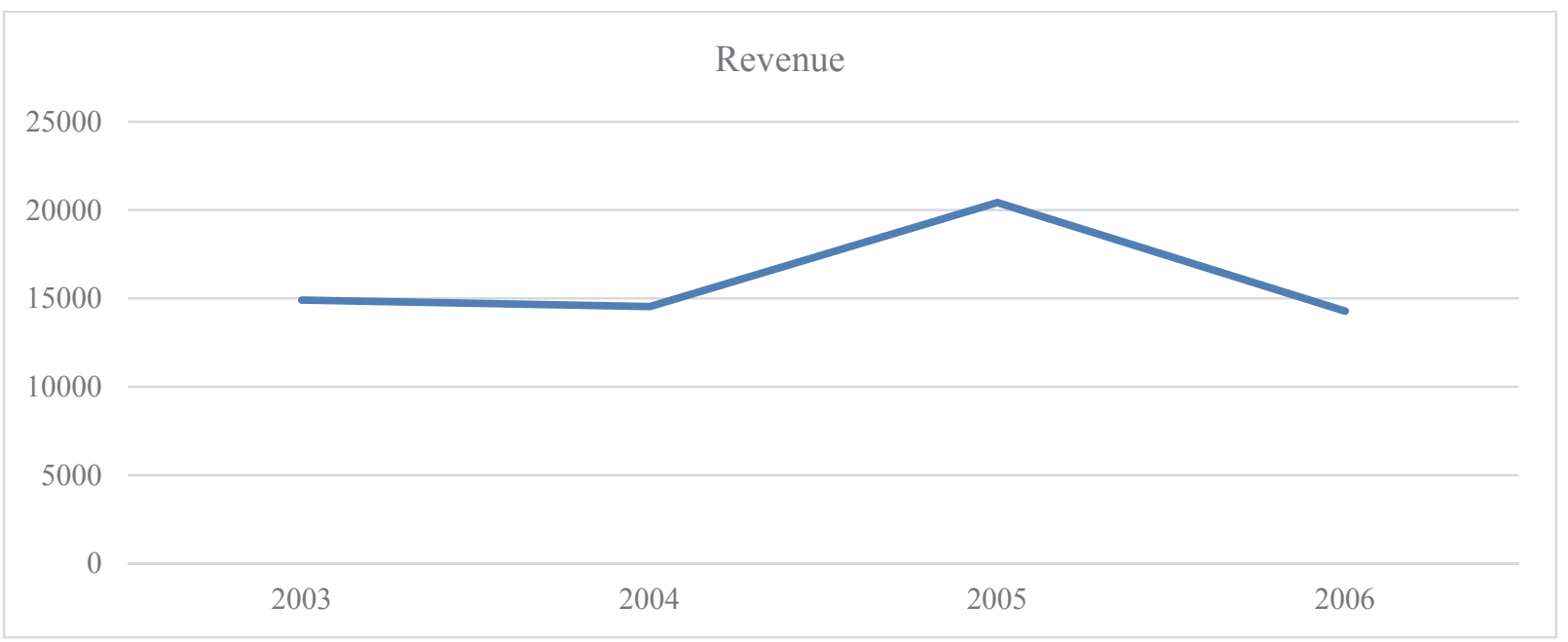

FIGURE 5

EQUITABLE PCI BANKS' ASSETS AND LIABILITIES FROM 2003 TO 2006

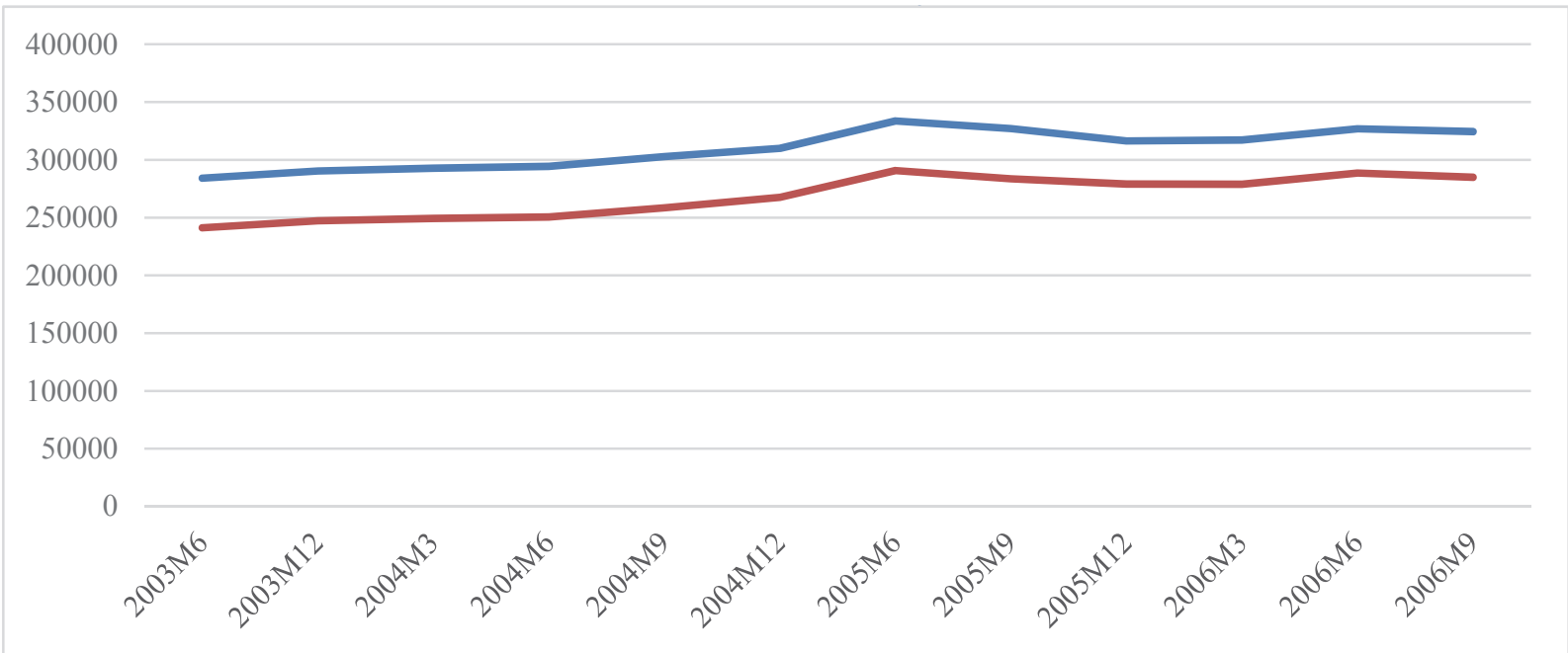

The blue for total assets and red for total liabilities 
FIGURE 6

REVENUES OF BDO BANK TILL 2006 AND BDO UNI BANK 2006 ONWARDS

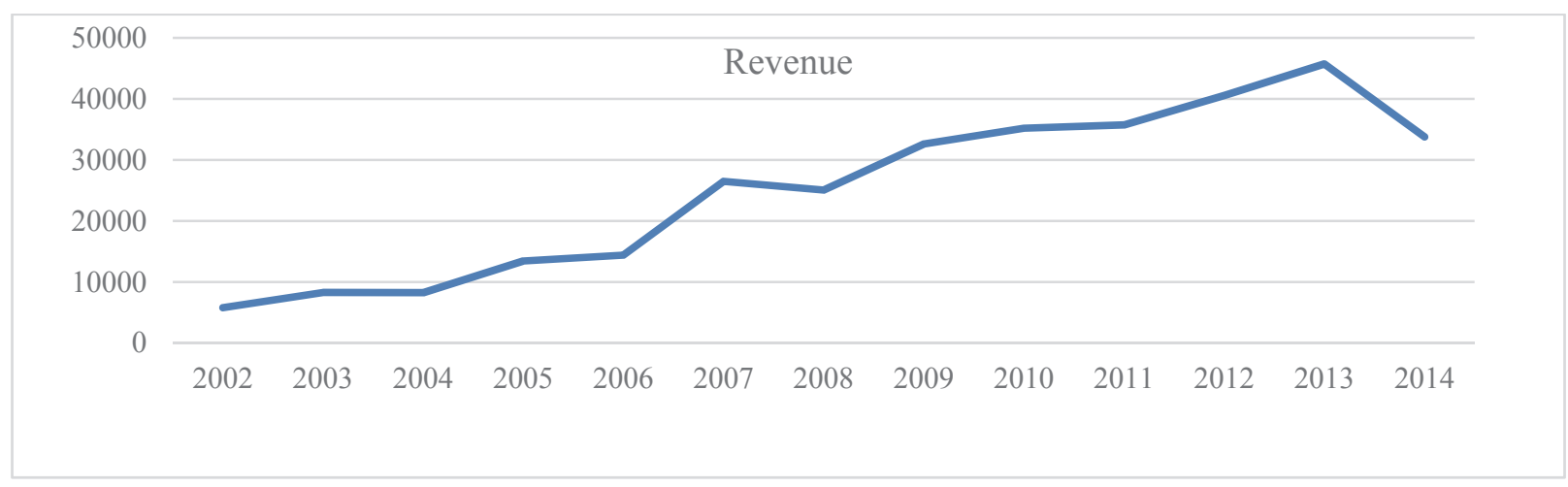

FIGURE 7

BALANCE SHEET DATA FOR BDO BANK TILL 2006 AND BDO UNI THEREON

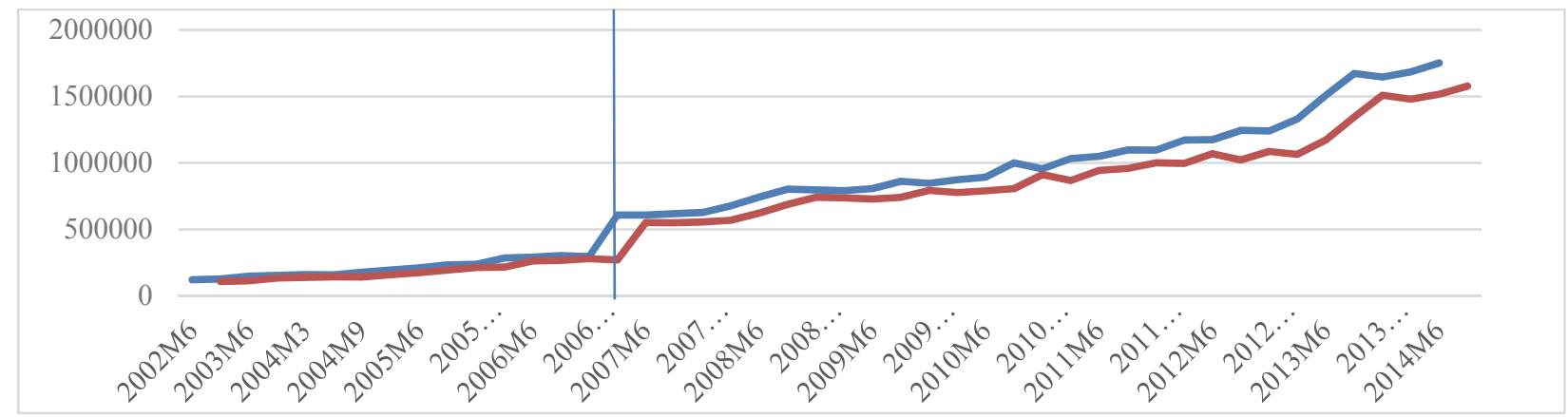

Note: Blue for total assets and red for total liabilities

Source: BDO, Equitable PCI and BDO Uni bank financial statements.

Figure 5 shows that Equitable PCI had a stable reserve of assets and liabilities during the 2003-2006 sample period. Figure 6 depict revenues of BDO till 2006 and BDO Uni bank for the 2006-2014 sample period. Figure 6 shows a significant upward trend and increases in revenue leading up to 2013. In addition, figure 7 shows total assets and liabilities of BDO up till 2006 and BDO Uni bank thereon for the 2006-2014 window. Figure 7 shows a prominent increase in assets and liabilities with the continuation of the upward trend observed before post-merger as well. Moreover, the merger resulted in BDO Uni banks' minimum capital required increasing to 700 million USD and subsequently settled with a market capitalization of 2 billion USD. Table 10 shows the present status of BDO Uni bank as the number one bank in Philippines, a decade from the merger. Table 11 shows the gradual increases in dividends per share (DPS) and diluted earnings per share (EPS). 
TABLE 10

PHILIPPINE BANK ASSET DETAILS IN MILLIONS OF PHP AS OF MARCH 2017

\begin{tabular}{lll}
\hline Ranking & Commercial Banks & Assets in millions of PHP \\
1 & BDO Uni bank & $2,262,034.65$ \\
2 & Metrobank & $1,589,447.27$ \\
3 & BPI & $1,451,377.01$ \\
4 & Land Bank & $1,375,686.17$ \\
5 & PNB & $740,419.12$ \\
6 & Security Bank & $729,174.82$ \\
7 & China Bank & $539,268.82$ \\
8 & DBP & $512,662.51$ \\
9 & Union Bank & $449,289.26$ \\
10 & RCBC & $425,287.94$ \\
\hline Source: Philippine Central Bank as of 2017
\end{tabular}

Source: Philippine Central Bank as of 2017.

TABLE 11

KEY ACCOUNTING VARIABLES FOR BDO UNI BANK FROM 2012-2016

\begin{tabular}{lccccc}
\hline & 2012 & 2013 & 2014 & 2015 & 2016 \\
\hline Revenue & $1,842.53 \mathrm{M}$ & $2,058.03 \mathrm{M}$ & $2,082.02 \mathrm{M}$ & $2,267.12 \mathrm{M}$ & $2,593.86 \mathrm{M}$ \\
Operating income & $370.50 \mathrm{M}$ & $568.50 \mathrm{M}$ & $605.49 \mathrm{M}$ & $698.90 \mathrm{M}$ & $707.53 \mathrm{M}$ \\
Income before tax & $370.50 \mathrm{M}$ & $568.50 \mathrm{M}$ & $595.10 \mathrm{M}$ & $657.08 \mathrm{M}$ & $682.66 \mathrm{M}$ \\
Net income & $343.03 \mathrm{M}$ & $532.33 \mathrm{M}$ & $513.75 \mathrm{M}$ & $549.40 \mathrm{M}$ & $549.40 \mathrm{M}$ \\
Diluted EPS & 0.1 & 0.13 & 0.13 & 0.14 & 0.14 \\
Dividends per share & 0 & 0.04 & 0.02 & 0.02 & 0.02 \\
Total assets & $30,256.09 \mathrm{M}$ & $37,715.99 \mathrm{M}$ & $41,698.54 \mathrm{M}$ & $43,202.72 \mathrm{M}$ & $46,796.85 \mathrm{M}$ \\
Total liabilities & $26,496.68 \mathrm{M}$ & $34,012.86 \mathrm{M}$ & $37,682.02 \mathrm{M}$ & $38,960.59 \mathrm{M}$ & $42,420.99 \mathrm{M}$ \\
Total equity & $3,743.41 \mathrm{M}$ & $3,688.63 \mathrm{M}$ & $4,002.36 \mathrm{M}$ & $4,228.88 \mathrm{M}$ & $4,360.91 \mathrm{M}$ \\
Operating cash flow & $683.45 \mathrm{M}$ & $869.91 \mathrm{M}$ & $774.68 \mathrm{M}$ & $180.22 \mathrm{M}$ & $891.45 \mathrm{M}$ \\
\hline
\end{tabular}




\section{TABLE 12 \\ SELECTED MERGERS, ACQUISITIONS AND CONSOLIDATION OF PHILIPPINE BANKS FROM 2004 TO Q1 2014}

\begin{tabular}{ll}
\hline Date & \multicolumn{1}{c}{ Activity } \\
\hline 2005 & $\begin{array}{l}\text { BDO Bank acquired 66 of the 67 Philippine branches of Singapore's United Overseas } \\
\text { Bank for 600 PHP million. }\end{array}$ \\
2005 & $\begin{array}{l}\text { BDO Bank purchased the Go family's 24.76\% stake in Equitable PCI Bank for } 10.2 \\
\text { Pbn. }\end{array}$ \\
2007 & $\begin{array}{l}\text { BDO Uni bank merged with Equitable PCI Bank, resulting in combined assets of } 613 \\
\text { Pbn and combined deposits of 435 Pbn. }\end{array}$ \\
2009 & $\begin{array}{l}\text { BDO Uni bank. Inc. acquired GE Money Bank for 1.3 Pbn. } \\
2012\end{array}$ \\
2013 & $\begin{array}{l}\text { BDO Unibank, Inc. acquired Rural Bank of San Juan, Inc., adding } 30 \text { branches to the } \\
\text { former } \\
\text { BDO Uni bank, Inc. signed an agreement to acquire 99.99\% of Citibank Savings, Inc., }\end{array}$ \\
& $\begin{array}{l}\text { Citi's thrift banking arm in the Philippines } \\
\text { BDO Uni bank, Inc. expressed interest in acquiring the trust business of Deutsche } \\
\text { Bank AG, Manila Branch, which adds 70 Pbn. }\end{array}$ \\
\end{tabular}

\section{CONCLUSION}

BDO Uni bank moved to the number one position in the Philippine Banking Industry following the merger of Equitable PCI bank (third largest bank) with BDO (the fifth largest bank). The acquisition was hailed as a bold precarious move driven by Hubris from the BDO management. This study provides a survey of literature on motives behind M\&A's and key factors that affect M\&A outcomes. In addition, this study identifies the following factors as key to the success of this particular merger and lessons that can be generalized to other bank mergers. 1. Successfully integrated two distinct banking cultures. 2 . Both management teams agreed upon the merger. 2. Both management teams had prior experience in mergers. 3. Revenue synergies were readily identified and utilized. 4. Cost efficiencies were identified and efficiently utilized. 5. Improved balance sheet management. 6. Affiliation of a large block-holder (SM group) provided better monitoring and a positive signal to the markets. Hence, due to efficient integration strategies and governance practices pursued by BDO management pre and post-merger the deal was a success. This particular merger provides evidence supporting value creation in M\&A's. Both banks were experienced in M\&A activity and the management agreed on the acquisition.

Despite initial skepticism, frictions and adverse reactions by various market participants, it has proven to greatly transform the Philippine's banking landscape. Finally, going forward a decade into the future, this particular merger still remains the most ambitious and controversial yet clearly a successful merger in the Philippine banking history. 


\section{REFERENCES}

Ahuja, G., \& Katila, R (2001). Technological acquisitions and the innovation performance of acquiring firms: A longitudinal Study. Strategic Management Journal, 22, 197-220.

Amihud, Y., \& Lev, B. (1981). Risk reduction as a managerial motive for conglomerate mergers. Bell Journal of Economics, 12, 605-617.

Appelbaum, S. H., Gandell, J., Shapiro, B. T., Belisle, P., \& Hoeven, E. (2000). Anatomy of a merger: behavior of organizational factors and process throughout the pre-duringpost-stages (part 2). Management Decision, 38(10), 674-684.

Berger, A. N., Demsetz, R. S., \& Strahan, P. E. (1999). The Consolidation of the Financial Services Industry: Causes, Consequences, and Implications for the Future. Journal of Banking and Finance, 23, 135-94.

Billett, M. T., \& Qian, Y. (2008). Are overconfident CEOs born or made? Evidence of self-attribution bias from frequent acquirers. Management Science, 54, 1037-1051.

Bradley, M., Desai, A., \& Kim, E. H. (1988). Synergistic Gains from Corporate Acquisitions and their Division between the Stockholders of Target and Acquiring Firms. Journal of Financial Economics, 21, 3-40.

Bris, A., \& Cabolis, C. (2008). The value of investor protection: evidence from cross-border mergers. Review of Financial Studies, 21, 2605-2648.

Buono, A. F., Bowditch, J. W., \& Lewis, J. W. (1985). When cultures collide: The anatomy of a merger. Human Relations, 38(5), 477-500.

Buono, A. F., \& Bowditch, J. L. (1989). The human side of mergers and acquisitions: Managing collisions between people and organizations. San Francisco: Jossey-Bass.

Capron, L., \& Hulland, J. (1999). Redeployment of brands, sales forces, and general marketing management expertise following horizontal acquisitions: a resource-based view. Journal of Marketing, 63(2), 41-54.

Cartwright, S., \& Cooper, C. L. (1992). Mergers and acquisitions: The human factor. Oxford: Butterworth-Heinemann Ltd.

Chang, S., \& Rosenzweig, P. (2001). The choice of entry mode in sequential foreign direct investment. Strategic Management Journal, 22(8), 747-777.

Chatterjee, S. (1992). Sources of value in takeovers: Synergy or restructuring-Implications for target and bidder firms. Strategic Management Journal, 13, 267-287.

Chatterjee, S., Lubatkin, M. H., Schweiger, D. M., \& Weber, Y. (1992). Cultural differences and shareholder value in related mergers: Linking equity and human capital. Strategic Management Journal, 13(5), 319-334.

Cunha, I. (2015). Case Study Preparation: The WhatsApp acquisition from Facebook (Doctoral dissertation. NOVA-School of Business and Economics.

Datta, D. K. (1991). Organizational fit and acquisition performance: Effects of post -acquisition integration. Strategic Management Journal, 12, 281-298.

Datta, S., Iskandar-Datta, M., \& Raman, K. (2001), Executive Compensation and Corporate Acquisition Decisions. The Journal of Finance, 56, 2299-2336

Datta, D. K., Pinches, G. E., \& Narayanan, V. K. (1992). Factors influencing wealth creation from mergers and acquisitions: A meta-analysis. Strategic Management Journal, 13, 67-84.

DeYoung, R., Evanoff, D. D., \& Molyneux, P. (2009). Mergers and Acquisitions of Financial Institutions: A Review of the Post-2000 Literature. Journal of Financial Services Research, 36, 87-110.

Doseck, K. E. (2012). A Phenomenological Study of HRM Practitioner Merger and Acquisition Integration Preparation: Perspectives on Organizational Culture. Human Capital Management, And Change Management, (7-12). Capella University, ProQuest, UMI Dissertation Publishing.

Doukas, J. A., \& Petmezas, D. (2007). Acquisitions, overconfident managers and self-attribution bias. European Financial Management, 13(3), 531-577.

158 Journal of Applied Business and Economics Vol. 22(1) 2020 
Doukas, J., \& Travlos, N. G. (1988), The Effect of Corporate Multinationalism on Shareholders' Wealth: Evidence from International Acquisitions. The Journal of Finance, 43, 1161-1175.

Forstmann, S. (1998). Managing cultural differences in cross-cultural mergers and acquisitions. In M. C. Galpin, T. J., \& Herndon, M. (2000). The Complete Guide to. Mergers and Acquisitions.

Galpin, T. J., \& Herndon, M. (2014). The complete guide to mergers and acquisitions: Process tools to support M\&A integration at every level. John Wiley \& Sons.

Golubov, A., Petmezas, D., \& Travlos, N. G. (2012). When It Pays to Pay Your Investment Banker: New Evidence on the Role of Financial Advisors in M\&As. The Journal of Finance, 67, 271-311.

Gort, M. (1969). An Economic Disturbance Theory of Mergers. Quarterly Journal of Economics, 83, 624-642.

Gutknecht, J. E., \& Keys, J. B. (1993). Mergers, acquisitions and takeovers: Maintaining morale of survivors and protecting employees. Academy of Management Perspectives, 7(3), 26-36.

Haleblian, J., Devers C. E., McNamara, G., Carpenter, M. A., \& Davison, R. B. (2009). Taking Stock of What We Know About Mergers and Acquisitions: A Review and Research Agenda. Journal of Management, 35(3),469-502.

Haleblian, J., \& Finkelstein, S. (1999). The influence of organizational acquisition experience on acquisition performance: A behavioral perspective. Administrative Science Quarterly, 44, 29-56.

Harford, J. (1999). Corporate cash reserves and acquisitions. The Journal of Finance, 54(6), 1969-1997.

Harford, J. (2005). What drives merger waves? Journal of Financial Economics, 77, 529-560.

Haspeslagh, P. C., \& Jemison, D. B. (1991). Managing acquisitions: Creating value through corporate renewal. New York: The Free Press.

Haunschild, P. R. (1993). Interorganizational imitation: the impact of interlocks on corporate acquisition activity. Administrative Science Quarterly, 38(4), 564-592.

Hayn, C. (1989). Tax Attributes as Determinants of Shareholder Gains in Corporate Acquisitions. Journal of Financial Economics, 23, 121-53.

Hayward, M. L. A. (2002). When do firms learn from their acquisition experience? Evidence from 1990 to 1995. Strategic Management Journal, 23(1), 21-39.

Hayward, M. L. A., \& Hambrick, D.C. (1997). Explaining the premium paid for large acquisitions: Evidence of CEO hubris. Administrative Science Quarterly, 42, 103-127.

Hoberg, G., \& Phillips, G. (2010). Product market synergies and competition in mergers and acquisitions: A text-based analysis. Review of Financial Studies, 23, 3773-3811.

Hofstede, G., Neuijen, B., Ohayv, D.D., \& Sanders, G. (1980). Measuring organizational cultures: a qualitative and quantitative study across twenty cases. Administrative Science Quarterly, 35, 286316.

Houston, J. F., James, C. M., \& Ryngaert, M. D. (2001). Where do merger gains come from? Bank mergers from the perspective of insiders and outsiders. Journal of Financial Economics, 60, 285331.

Idris, S. A. M., Wahab, R. A. W., \& Jaapar, A. (2015). Corporate Cultures Integration and Organizational Performance: A Conceptual Model on the Performance of Acquiring Companies. Procedia Social and Behavioural Sciences, 172, 591-595.

Ivancevich, J. M., Schweiger, D. M., \& Power, F. R. (1987). Strategies for managing human resources during mergers and acquisitions. Human Resource Planning, 10(1), 19-35.

Jemison, D. B., \& Sitkin, S. B. (1986). Corporate acquisitions: A process perspective. Academy of Management Review, 11(1), 145-163.

Jensen, M. C. (1986). Agency Costs of Free Cash Flow, Corporate Finance, and Takeovers. American Economic Review, 76, 323-29.

Jensen, M. C. (1993). The Modern Industrial Revolution, Exit, and Control Systems. Journal of Finance, $48,831-80$.

Jensen, M. C., \& Ruback, R S. (1983). The Market for Corporate Control: The Scientific Evidence. Journal of Financial Economics, 11, 5-50.

Journal of Applied Business and Economics Vol. 22(1) 2020159 
Kesner, I.F., Shapiro, D.L., \& Sharma, A. (1994). Brokering mergers: An agency theory perspective on the role of representatives. Academy of Management Journal, 37, 703-21.

Kolasinsiki, A.C., \& Li, X. (2013). Can strong boards and trading their own firm's stock help CEOs make better decisions? Evidence from acquisitions by overconfident CEOs. Journal of Financial and Quantitative Analysis.

Krishnan, H. A., Miller, A., \& Judge, W.Q. (1997). Diversification and top management team complementarity: Is performance improved by merging similar or dissimilar teams? Strategic Management Journal, 18, 361-374.

Kroll, M., Wright, P., Toombs, L., \& Leavell, H. (1997). Form of control: A critical determinant of acquisition performance and CEO rewards. Strategic Management Journal, 18(2), 85-96.

Krug, J. A., Wright, P., \& Kroll, M. J. (2013). Top Management Turnover Following Mergers and Acquisitions: Solid Research to Date but Still Much to Be Learned. Academy of Management Perspectives, 28(2), 147-163.

Kusewitt, J. B. (1985). An exploratory study of strategic acquisition factors relating to performance. Strat. Mgmt. J., 6, 151-16.

Kusewitt, J. B., Jr. (1983). Mergers and the performance of the acquiring firm. Academy of Management Review, 8, 218-26.

Larsson, R., \& Finkelstein, S. (1991). Integrating Strategic, Organizational, and Human Resource Perspectives on Mergers and Acquisitions: A Case Survey of Synergy Realization. Organisational Science, 10(1), 1-26.

Lewellen, W., Loderer, C., \& Rosenfeld, A. (1985). Merger decisions and executive stock ownership in acquiring firms. Journal of Accounting and Economics, 7, 209-231.

Lin, C. (2007). Knowledge sharing and firm innovation capability: an empirical study. International Journal of Manpower, 28(3/4), 315-332.

Lin, C., Officer, M.S., \& Zou, H. (2011). Directors' and officers' liability insurance and acquisition outcomes. Journal of Financial Economics, 102(3), 507-525.

Lin, B., Hung, S-C., \& Li, P-C. (2006). Mergers and Acquisitions as a Human Resource Strategy: Evidence from Us Banking Firms. International Journal of Manpower, 27(2), 126- 142.

Lodorfos, G., \& Boateng, A. (2006). The Role of Culture in The Merger and Acquisition Process: Evidence from The European Chemical Industry. Management Decision, 44(10), 1405-1421.

Lubatkin, M. (1983). Mergers and the performance of the acquiring firm. Academy of Management Review, 8, 218-226.

Malmendier, U., \& Tate, G. (2008). Who makes acquisitions? CEO overconfidence and the market's reaction. Journal of Financial Economics, 89, 20-43.

Manzon, G. B., Jr., Sharp, D. J., \& Travlos, N. G. (1994). An empirical study of the consequences of U.S. tax rules for international acquisitions by U.S. firms. Journal of Finance, 49, 1893-1904.

Marks, M. L., \& Mirvis, P.H. (1998). Joining forces: Making one plus one equal three in mergers, acquisitions, and alliances. San Francisco: Jossey-Bass Publishers. Mergers and Acquisitions. 1990. The M\&A Rosters, 24(5), 123.

Marfo, E. O., Amoako, K. O., \& Gyau, E. K. (2013). Mergers and Acquisitions: The Performance of the Acquiring Firm-Empirical Study of Cheverontexaco. Canadian Social Science, 9(5), 176-187.

Masulis, R. W., Wang, C., \& Xie, F. (2007). Corporate governance and acquirer returns. Journal of Finance, 62, 1851-1889.

Melkonian, T., Monin, P., \& Noorderhaven, N. G. (2011). Distributive justice, procedural justice, exemplarity, and employees' willingness to cooperate in M\&A integration processes: An analysis of the Air France-KLM merger. Human Resource Management, 50(6), 809-837.

Mitchell, M. L., \& Mulherin, J. H. (1996). The Impact of Industry Shocks on Takeover and Restructuring Activity. Journal of Financial Economics, 41, 193-229.

Mitleton, K. E. (2006). Co-Evolutionary Integration: The Co-Creation of New Organisational Form Following Merger and Acquisition. Emergence, 8(2), 36-47.

160 Journal of Applied Business and Economics Vol. 22(1) 2020 
Mohibullah, A. (2009). Impact of culture on mergers and acquisitions: A theoretical framework. International Review of Business, 5(1), 255-264.

Morck, R., Shleifer, A., \& Vishny, R. W. (1988). Characteristics of Hostile and Friendly Takeovers. In Auerbach, A. J. ed. Corporate Takeovers: Causes and Consequences. Chicago: University of Chicago Press / NBER.

Nahavandi, A., \& Malekzadeh, A.R. (1988). Acculturation in mergers and acquisitions. Academy of Management Review, 13, 79-91.

Pfeffer, J. (1972). Merger as a response to organizational interdependence. Administrative Science Quarterly, 382-394.

Rhodes-Kroph, M., Robinson, D. T., \& Viswanathan, S. (2005). Valuation waves and merger activity: The empirical evidence. Journal of Financial Economics, 77(3), 561-603.

Rhodes-Kroph, M., \& Viswanathan, S. (2004). Market valuation and merger waves. The Journal of Finance, 59(6), 2685-2718.

Roll, R. (1986). The hubris hypothesis of corporate takeovers. Journal of Business, 59, 197-216.

Rottig, D., Reus, T. H., \& Tarba, S. Y. (2014). The Impact of Culture on Mergers and Acquisitions: A Third of a Century of Research. In C.L.

Saunders, M. N., Altinay, L., \& Riordan, K. (2009). The management of post-merger cultural integration: implications from the hotel industry. The Service Industries Journal, 29(10), 1359-1375.

Schmidt, D. R., \& Fowler, K. L. (1990). Post-acquisition financial performance and executive compensation. Strategic Management Journal, 11, 559-570.

Scholes, M. S., \& Wolfson, M. A. (1990). The effects of changes in tax laws on corporate reorganization activity. Journal of Business, 63, S141-S164.

Schweiger, D. M., \& DeNisi, A. S. (1991). Communication with employees following a merger: A longitudinal field experiment. Academy of Management Journal, 34(1), 110-135.

Schweiger, D. M., Csiszar, E. N., \& Napier, N. K. (1993). Implementation international mergers and acquisitions. HR.Human Resource Planning, 16(1), 53-70.

Schweiger, D. M., \& Goulet, P. K. (2005). Facilitating acquisition integration through deep-level cultural learning interventions: A longitudinal field experiment. Organization Studies, 26(10), 1477-1499.

Schweiger, D. M., Ivancevich, J. M., \& Power, F. R. (1987). Executive actions for managing human resources before and after acquisitions. Academy of Management Executive, 1(1), 127-38.

Schweiger, D. M., \& Weber, Y. (1989). Strategies for managing human resources during mergers and acquisitions: an empirical investigation. Human Resource Planning Journal, 12(2), 69-86.

Seth, A. (1990). Value creation in acquisitions: A re-examination of performance. Strategic Management Journal, 11, 99-116.

Shanley, M. T., \& Correa, M. E. (1992). Agreement between top management teams and expectation for post acquisition performance. Strategic Management Journal, 13, 245-267.

Shleifer, A., \& Vishny, R. W. (1991). Takeovers in the '60s and '80s: Evidence and implications. Strategic Management Journal, 12, 51-59.

Shleifer, A., \& Vishny, R. W. (2003). Stock Market Driven Acquisitions. Journal of Financial Economics, 70(3), 295-311.

Sinclair, R., \& Keller, K. L. (2017). Brand value, accounting standards, and mergers and acquisitions: "The Moribund Effect". Journal of Brand Management, 24(2), 178-192.

Singh, D., Pattnaik, C., Gaur, A. S., \& Ketencioglu, E. (2018). Corporate expansion during pro-market reforms in emerging markets: The contingent value of group affiliation an diversification. Journal of Business Research, 82, 220-29.

Singh, H., \& Zollo, M. (1998). The impact of knowledge codification, experience trajectories and integration strategies on the performance of corporate acquisitions. Academy of Management Proceedings.

Sirower, M. L. (1997). The synergy trap: How companies lose the acquisition game. New York. The Free Press. 
Spoor J. R., \& Mei-Tai, C. (2017). The Role of Social Identity and Communities of Practice in Mergers and Acquisitions. Group and Organizational Management.

Waddock \& Graves. (2006). The Impact of Publishing. Journal of Corporate Citizenship, 22, 1-20.

Walsh, J. P. (1988). Top management turnover following mergers and acquisitions. Strategic Management Journal, 9(2), 173-183.

Wang, C., \& Xie, F. (2009). Corporate governance transfer and synergistic gains from mergers and acquisitions. Review of Financial Studies, 22, 829-858.

Weber, Y., \& Tarba, S. Y. (2012). Mergers and Acquisitions Process: The Use of Corporate Culture Analysis. Cross Cultural Management. An International Journal, 19(3), 288-303.

Xing, Y., \& Liu, Y. (2016). Linking leaders' identity work and human resource management involvement: the case of sociocultural integration in Chinese mergers and acquisitions. The International Journal of Human Resource Management, 27(20), 2550-2577.

Zaheer, A., Castañer, X., \& Souder, D. (2013). Synergy Sources, Target Autonomy, And Integration in Acquisitions. Journal of Management, 39(3), 604-632.

162 Journal of Applied Business and Economics Vol. 22(1) 2020 